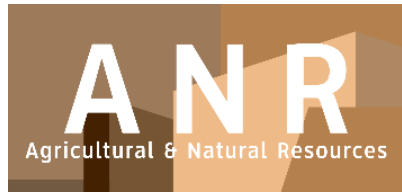

PAPER - OPEN ACCESS

\title{
Pengembangan Ekowisata Batu Katak Melalui Metode Swot Analisis
}

\author{
Author \\ : Yayuk Yuliana \\ DOI \\ : 10.32734/anr.v1i2.243 \\ Electronic ISSN \\ : 2654-7023 \\ Print ISSN \\ : 2654-7015 \\ Volume 1 Issue 2 - 2018 TALENTA Conference Series: Agricultural \& Natural Resources (ANR)
}

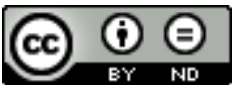

This work is licensed under a Creative Commons Attribution-NoDerivatives 4.0 International License.

Published under licence by TALENTA Publisher, Universitas Sumatera Utara
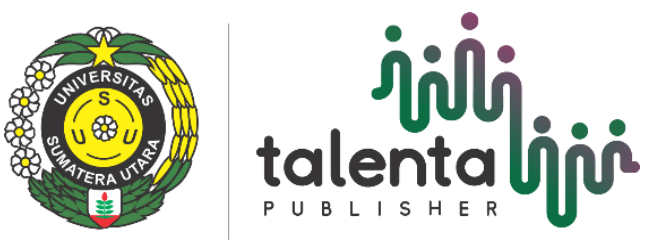
Available online at https://talentaconfseries.usu.ac.id

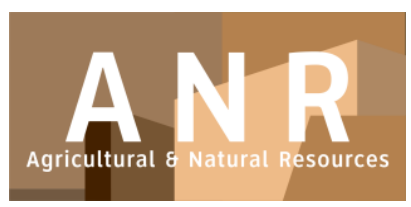

\title{
Pengembangan Ekowisata Batu Katak Melalui Metode Swot Analisis
}

\author{
Yayuk Yuliana*, Slamet Indarjo ${ }^{\mathrm{b}}$ \\ ${ }^{a}$ Fakultas Ekonomi, Universitas Muslim Nusantara Al Washliyah, Medan, Indonesia \\ ${ }^{b}$ Balai Besar Taman Nasional Gunung Leuser, Medan, Indonesia
}

\begin{abstract}
Abstrak
Pengembangan ekowisata merupakan salah satu upaya untuk menjaga kelestarian hutan sebagai sumberdaya alam hayati dan mensejahterakan masyarakat di sekitarnya. Dusun Batu Katak merupakan salah satu dusun yang berada di daerah penyangga Taman Nasional Gunung Leuser. Sejak tahun 2013 masyarakat Dusun Batu Katak telah membuka Ekowisata Batu Katak. Wisatawan yang berkunjung ke Ekowisata Batu Katak terus mengalami peningkatan. Penelitian yang dilakukan bertujuan untuk mengetahui faktor-faktor dalam pengembangan Ekowisata Batu Katak. Metode pengumpulan data dengan melakukan studi literatur, observasi lapangan, wawancara dengan masyarakat dan stakeholder. Analisis data dengan menggunakan analisis SWOT untuk merumuskan alternatif-alternatif strategi. Hasil penyusunan alternatif-alternatif strategi diketahui terdapat 11 alternatif strategi. Perencanaan Ekowisata masih tetap mempertahankan kondisi alami dengan penataan ruang, sirkulasi ekowisata yang tetap menjamin kenyamanan pengunjung dan penduduk.
\end{abstract}

Kata Kunci: Batu Katak; Ekowisata; Analisis SWOT;

\section{Pendahuluan}

Masyarakat di dusun Batu Katak pada tahun 2013 telah membentuk Lembaga Pariwisata Batu Katak (LPBK) saat ini anggotanya berjumlah 57 orang. Dusun Batu Lembaga Katak menjadi Model Desa Konservasi yang dibina oleh Balai Besar Taman Nasional Gunung Leuser (TNGL) pada tahun 2014. Masyarakat di dusun Batu Katak diharapkan dapat terlibat secara aktif untuk menjaga sumberdaya alam dan lingkungan dalam hal ini kawasan TNGL serta ekosistem di sekitarnya.

Daya tarik di Ekowisata Batu Katak yaitu aliran sungai Berkail yang masih jernih dan banyak terdapat batu-batu, terdapat 8 goa karst, terdapat bunga bangkai (Amorphophallus titanum) yang mudah dijumpai, terdapat bunga rafflesia (Rafflesia lawangensis) yang berada dalam kawasan TNGL, terdapat berbagai jenis satwa liar seperti orangutan sumatera (pongo abelii), siamang atau gibbon (Hylobates syndactylus), beruang madu (Helarctos malayanus) dan harimau sumatera (Panthera tigris sumatrensis). Panorama sungai Berkail, goa-goa dan tumbuhan langka merupakan daya tarik yang menjadi ciri khas Batu Katak. Keberadaan satwa liar merupakan daya tarik di Batu Katak namun tidak selalu bisa dilihat secara langsung. 
Karakteristik gua di kecamatan Bahorok dikategorikan gua ilmiah dengan tingkat kemudahan yang tinggi, masyarakat setempat lebih menghendaki goa-goa dijadikan lokasi wisata petualang dengan harapan mendapat tambahan pendapatan [1]. Potensi keanekaragaman flora dan fauna merupakan modal pengembangan ekowisata yang prinsipnya adalah pendidikan konservasi lingkungan terhadap pengunjung dan masyarakat setempat [2].

Pengembangan ekowisata harus sesuai dengan konsep pariwisata yang berkelanjutan (sustainable tourism), berwawasan lingkungan dan pemberdayaan masyarakat, yaitu masyarakat berperan dalam pengelolaan sumberdaya alam dan lingkungan sebagai aset [3]. Pengembangan Ekowisata Batu Katak perlu dilakukan dengan perencanaan untuk jangka pendek, jangka menengah dan jangka panjang untuk menentukan strategi yang sesuai dengan kondisi di ekowisata Batu Katak.

Strategi yang digunakan dalam pengembangan Ekowisata Batu Katak harus dilakukan kajian. Hingga saat ini penelitian terkait dengan pengembangan ekowisata di Batu Katak belum pernah dilakukan. Penelitian yang akan dilakukan menggunakan analisis SWOT (Strenght, Weakness, Opportunity, Threats) untuk menentukan alternatifalternatif strategi dalam pengembangan Ekowisata Batu Katak. Tujuan utama dari penelitian ini adalah untuk merumuskan strategi dalam pengelolaan dan pengembangan pariwisata alam di Dusun Batu Katak.

\section{Bahan dan Metode}

\subsection{Lokasi Penelitian}

Penelitian berlokasi di dusun Batu Katak, desa Batu Jong Jong, kecamatan Bahorok, kabupaten Langkat adalah salah satu daerah penyangga TNGL (Gambar 1).

\subsection{Metode}

Alat yang digunakan pada penelitian ini antara lain yaitu : alat tulis, alat perekam dan kamera. Bahan yang digunakan dalam penelitian yaitu : panduan wawancara dan peta dari image citra SPOT 4 tahun 2012.

Analisis SWOT adalah identifikasi berbagai faktor secara sistematis untuk merumuskan strategi perusahaan. Analisis ini didasarkan pada logika yang dapat memaksimalkan kekuatan (strengths) dan peluang (opportunities), namun secara bersamaan dapat meminimalkan kelemahan (weaknesses) dan ancaman (threats). Proses pengambilan keputusan strategis selalu berkaitan dengan pengembangan misi, tujuan dan kebijakan perusahaan. Dengan demikian perencanaan strategis harus menganalisis faktor-faktor strategis perusahaan (kekuatan, kelemahan, peluang dan ancaman) dalam kondisi yang ada saat ini [4].

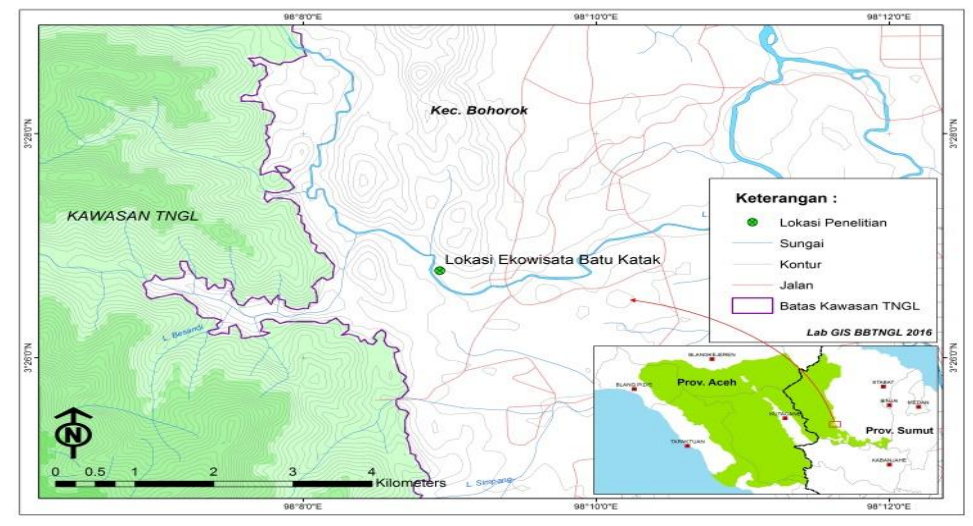




\section{Hasil}

\subsection{Kondisi Umum Lokasi Penelitian}

Ekowisata Batu Katak terletak di Dusun Batu Katak, Desa Batu Jong-Jong, Kecamatan Bahorok. Jarak lokasi Ekowisata Batu Katak ke Ibu Kota Kecamatan sejauh 8 km, berjarak 80 km dari Ibu Kota Kabupaten Langkat di Stabat, dan berjarak $80 \mathrm{~km}$ dari Ibu Kota Propinsi Sumatera Utara di Medan. Desa Batu Jong-Jong merupakan desa yang paling luas di Kecamatan Bahorok dengan luas 300,16 km² atau 27,24 \% dari total luas Kecamatan Bahorok.

\subsection{Kondisi Sosial dan Ekonomi}

Penduduk Dusun Batu Katak terdiri dari 60 Kepala Keluarga (KK) dengan jumlah laki-laki 101 orang dan perempuan 120 orang. Jumlah penduduk berdasarkan kelas umur dan jenis kelamin dapat dilihat pada Tabel 1.

Tabel 1. Penduduk di Dusun Batu Katak, Desa Batu Jong-Jong, Kecamatan Bahorok, Kabupaten Langkat

\begin{tabular}{lll}
\hline Kelas Umur & Laki-Laki & Perempuan \\
\hline $0-5$ tahun & 10 & 14 \\
$5-15$ tahun & 13 & 15 \\
$15-35$ tahun & 42 & 45 \\
$35-45$ tahun & 14 & 14 \\
$45-60$ tahun & 18 & 22 \\
$>60$ tahun & 4 & 10 \\
Jumlah & 101 & 120 \\
\hline
\end{tabular}

Sumber: Survei Lapangan

Kelas umur 0-15 tahun berjumlah 52 orang, usia produktif antara 15-60 tahun berjumlah 155 orang, dan usia diatas 60 tahun berjumlah 14 orang. Sebanyak 14 orang penduduk yang berusia produktif saat ini terlibat sebagai pemandu Ekowisata Batu Katak. Suku di Dusun Batu Katak terdiri dari suku Karo, Jawa, dan Melayu (Tabel 2)

Tabel 2. Persentase Penduduk Dusun Batu Katak Menurut Suku

\begin{tabular}{lcc}
\hline Suku & Jumlah & Persentase \\
\hline Karo & 196 & 88 \\
Jawa & 21 & 10 \\
Melayu & 4 & 2 \\
Total & 168 & 100 \\
\hline
\end{tabular}

Sumber: Survei Lapangan

Penduduk dusun Batu Katak memiliki tingkat pendidikan dari tidak tamat Sekolah Dasar (SD) hingga tamat perguruan tinggi (diploma dan S1 (sarjana)). Kesadaran masyarakat di Dusun Batu Katak akan pentingnya pendidikan sudah baik, penduduk yang tidak tamat SD hanya yang berusia diatas 45 tahun. Penduduk yang tamat Sekolah Lanjutan Pertama (SLTP) dan Perguruan Tinggi berjumlah 123 orang (Tabel 3). 
Tabel 3. Pendidikan Penduduk di Dusun Batu Katak, Desa Batu Jong-Jong, Kecamatan Bahorok, Kabupaten Langkat (Umur >15 tahun)

\begin{tabular}{lll}
\hline Pendidikan & Jumlah & Persentase \\
\hline S1/Diploma & 4 & 2 \\
SLTA & 51 & 30 \\
SLTP & 68 & 40 \\
SD & 30 & 5,7 \\
Tidak Tamat SD & 16 & 4,3 \\
Total & 169 & 100 \\
\hline
\end{tabular}

\section{Sumber: Survei Lapangan}

Pendapatan keluarga di Desa Batu Jong-Jong rata-rata sebesar Rp 2.150.000,- per bulan. Hasil produksi pertanian dan perkebunan masih menjadi andalan Desa Batu Jong-Jong dapat dilihat pada Tabel 4.

Tabel 4. Pekerjaan Penduduk Dusun Batu Katak, Desa Batu Jong-Jong, Kecamatan Bahorok

\begin{tabular}{ll}
\hline Pekerjaan & Jumlah (KK) \\
\hline Petani & 38 \\
Petani dan Pedagang & 4 \\
Petani dan Pemandu & 14 \\
Pedagang & 2 \\
Pegawai Negeri Sipil & 2 \\
Jumlah & 60 \\
\hline
\end{tabular}

Sumber: Survei Lapangan

Penduduk Dusun Batu Katak yang bekerja dalam bidang pertanian sebanyak 56 KK, pekerjaan sebagai pedagang dan pemandu merupakan pekerjaan sampingan. Penduduk yang menjadi PNS bekerja sebagai guru SD dan bidan desa. Penduduk yang menjadi pedagang saja hanya $2 \mathrm{KK}$ dengan membuka warung makan.

Fasilitas penunjang yang sudah ada di dusun Batu Katak yaitu warung kopi, warung makan, toilet umum, camping ground dan jembatan gantung (Tabel5). Fasilitas berada di sekitar sungai berkail yang pemiliknya adalah masyarakat dusun Batu Katak.

Tabel 5. Fasilitas Penunjang di Ekowisata Batu Katak Kecamatan Bahorok Kabupaten Langkat

\begin{tabular}{lll}
\hline Fasilitas Penunjang & Jumlah & Keterangan \\
\hline Warung Kopi \& Kedai & 4 & Milik Perseorangan \\
Warung Makan & 2 & Milik Perseorangan \\
Toilet Umum & 5 & Milik Perseorangan \\
Camping Ground & 1 & Milik Perseorangan \\
Jembatan Gantung & 1 & Milik Umum \\
\hline
\end{tabular}

Sumber: Survey Lapangan 
Masing-masing warung kopi dan warung makan berkapasitas 10 orang. Menu yang disajikan adalah masakan tradisional Karo, Jawa dan Melayu. Toilet umum tidak dikenakan biaya, ini merupakan fasilitas untuk para pengunjung.

Penginapan di Ekowisata Batu Katak saat ini sebanyak 5 tempat, pemilik penginapan adalah penduduk Batu Katak (Tabel 6).

Tabel 6. Penginapan di Ekowisata Batu Katak

\begin{tabular}{lll}
\hline Nama Penginapan & Jumlah Kamar & Pemilik \\
\hline Batu Kata Guest House \& Restoran & 6 & Ibu Mes \\
Orchid Bungalow \& Restoran & 4 & Darwin Ginting \\
Puliken House & 2 & Peuliken Sembiring \\
Rusli Guest House & 3 & Rusdi Sinulingga \\
Serasi Home & 1 & Serasi Singarimbun \\
\hline Total & 16 & \\
\hline
\end{tabular}

Sumber: Survey Lapangan

Penginapan yang dilengkapi dengan restoran sebanyak 2 tempat dengan kapasitas masing-masing restoran 25 orang. Penginapan yang lain berada di pemukiman penduduk di Dusun Batu Katak. Tarif penginapan berkisar antara Rp100.000,- hingga Rp200.000,- per malam.

\section{Pembahasan}

Hasil analisis faktor-faktor internal dan eksternal disintesis dalam Matrik SWOT untuk merumuskan alternatifalternatif strategi yang akan dijadikan pedoman dalam pengembangan Ekowisata Batu Katak (Tabel 7).

Tabel 7. Matrik SWOT

\begin{tabular}{|c|c|c|}
\hline Faktor Eksternal & $\begin{array}{l}\text { Strengths } \mathbf{S} \\
\text { 1. Daya tarik wisata } \\
\text { 2. Jarak dari Medan } \\
\text { 3. Atraksi wisata } \\
\text { 4. Masyarakat mendukung ekowisata } \\
\text { 5. Kesadaran pelaku wisata } \\
\text { 6. Manajemen risiko }\end{array}$ & $\begin{array}{l}\text { Weakness } \mathbf{W} \\
\text { 1. Pemasaran masih kurang } \\
\text { 2. Penataan kawasan belum dilakukan } \\
\text { 3. Kemampuan pemodalan rendah } \\
\text { 4. Sarana dan prasarana masih kurang }\end{array}$ \\
\hline $\begin{array}{l}\text { Opportunities } \mathbf{O} \\
\text { 1. Tren kembali ke alam (back to } \\
\text { nature) } \\
\text { 2. Tren kembali ke tradisional } \\
\text { 3. Kondisi politik stabil } \\
\text { 4. Peranan pemerintah } \\
\text { 5. Penelitian dan Pendidikan } \\
\text { 6. Penegakan Hukum Tindak } \\
\text { Pidana Kehutanan } \\
\text { 7. Kerjasama dengan wisata } \\
\text { tempat lain (Bukit Lawang dan }\end{array}$ & $\begin{array}{l}\text { Strategi SO } \\
\text { 1. Menggunakan daya tarik wisata alam, } \\
\text { dukungan masyarakat, kesadaran pelaku } \\
\text { wisata, lokasi yang mudah dijangkau, dan } \\
\text { manajemen risiko yang baik untuk } \\
\text { memanfaatkan tren dunia kembali ke alam } \\
\text { dan nilai-nilai tradisional. } \\
\text { 2. Menggunakan daya tarik wisata alam, } \\
\text { dukungan masyarakat, kesadaran pelaku } \\
\text { wisata, lokasi yang mudah dijangkau, dan } \\
\text { manajemen risiko yang baik untuk menjadi }\end{array}$ & $\begin{array}{l}\text { Strategi WO } \\
\text { 4. Bersama dengan pemerintah dan pelaku wisata } \\
\text { lainnya dalam pemasaran untuk memanfaatkan } \\
\text { tren dunia kembali ke alam dan tren kembali ke } \\
\text { tradisional } \\
\text { 5. Penataan kawasan melibatkan pemerintah } \\
\text { daerah, BBTNGL, dan akademisi dalam } \\
\text { menyusun lanskap dengan meminimalkan } \\
\text { dampak dan tetap mempertahankan kondisi saat } \\
\text { ini } \\
\text { 6. Mendorong tumbuhnya usaha kecil menengah }\end{array}$ \\
\hline
\end{tabular}




\begin{tabular}{|c|c|c|}
\hline Tangkahan) & $\begin{array}{l}\text { mitra pemerintah dalam menjaga kelestarian } \\
\text { alam dan lingkungan dan pengembangan ilmu } \\
\text { pengetahuan. } \\
\text { 3. Menjalin kerjasama dengan wisata di } \\
\text { sekitarnya tumbuh menjadi kawasan } \\
\text { ekowisata regional di bagian utara Sumatera. }\end{array}$ & $\begin{array}{l}\text { dengan memanfaatkan program fasilitasi dari } \\
\text { pemerintah. } \\
\text { 7. Pengadaan sarana dan prasarana (visitor center } \\
\text { musholla, toilet umum, , kios souvenir, papan } \\
\text { informasi, penunjuk arah) dengan } \\
\text { memanfaatkan dana desa dan hasil restribusi }\end{array}$ \\
\hline Threat T & Strategi ST & Strategi WT \\
\hline \multirow[t]{3}{*}{$\begin{array}{l}\text { 1. Kondisi ekonomi nasional dan } \\
\text { global rendahnya harga hasil } \\
\text { perkebunan dan nilai tukar } \\
\text { rupiah yang melemah }\end{array}$} & $\begin{array}{l}\text { 8. Memanfaatkan daya tarik wisata alam dan } \\
\text { atraksi wisata dengan menawarkan wisata } \\
\text { yang ekonomis yang tetap memuaskan }\end{array}$ & $\begin{array}{l}\text { 9. Meningkatkan pemasaran dengan membuat } \\
\text { paket wisata dengan harga bersaing pemasaran } \\
\text { menggunakan media masa online dalam bahasa } \\
\text { Indonesia dan bahasa asing. }\end{array}$ \\
\hline & & $\begin{array}{l}\text { 10. Menggunakan bahan baku lokal untuk } \\
\text { mengahasilkan produk-produk kerajinan yang } \\
\text { khas dengan harga terjangkau. }\end{array}$ \\
\hline & & $\begin{array}{l}\text { 11. Melakukan pengelolaan sarana dan prasarana } \\
\text { yang profesional untuk menjamin kenyamanan } \\
\text { pengunjung }\end{array}$ \\
\hline
\end{tabular}

Terdapat 11 alternatif strategi dalam pengembangan ekowisata Batu Katak. Strategi pemberdayaan masyarakat perlu dikaitkan dengan upaya menghentikan degradasi hutan serta peningkatan kesejahteraan masyarakat dan pemanfaatan yang optimal secara lestari[5]. Pengembangan ekowisata prioritas pertama adalah meningkatan pemahaman pemangku kepentingan (stakeholder) akan pentingnya ekosistem [6].

\section{Kesimpulan dan Saran}

\subsection{Kesimpulan}

Strategi yang diprioritaskan adalah menjadi mitra pemerintah dan akademisi dalam menjaga kelestarian alam dan lingkungan dan pengembangan ilmu pengetahuan, Memanfaatkan tren dunia kembali ke alam dan kembali ke nilainilai tradisional, dan tumbuh bersama wisata di sekitarnya menjadi kawasan wisata regional di bagian utara Sumatera;

\subsection{Saran}

Pemerintah kabupaten Langkat dan Balai Besar TNGL harus memperhatikan perkembangan Ekowisata Batu Katak dengan bersama LPBK menjadi pengendali setiap kebijakan dan program dalam pengelolaan Ekowisata Batu Katak.

\section{Referensi}

[1]. Zahedi. 2002. Studi Karakteristik dan Potensi Pengembangan Gua-Gua Karst di Kecamatan Bahorok Kabupaten Langkat (Tesis). Medan: Universitas Sumatera Utara, Program Pascasarjana.

[2]. Purnomo, H., Sulistyantara, B., dan Gunawan, A. 2013. Peluang Usaha Ekowisata di Kawasan Cagar Alam Pulau Sempu, Jawa Timur. Jurnal Penelitian Sosial Dan Ekonomi Kehutanan. 10 (4) : 247-263.

[3]. Attar, M., Hakim, L., Yanuwiadi, B. 2013. Analisis Potensi Dan Arahan Strategi Kebijakan Pengembangan Desa Ekowisata di Kecamatan Bumiaji-Kota Batu. Journal of Indonesian Tourism and Development Studies1(2) : 68-78. 
[4]. Rangkuti, F. 2014. Analisis SWOT Teknik Membedah Kasus Bisnis ( Cara Perhitungan Bobot, Rating, dan OCAI). Jakarta : PT Gramedia Pustaka Utama.

[5]. Prtidina, G dan Purnamasari, I. 2012. Telaah Model Pemberdayaan Masyarakat Melalui Kebijakan "Kampung Konservasi” Di Sekitar Wilayah Taman Nasional Gunung Halimun Salak. Jurnal Social Humaniora. 3 (1) : 44-57.

[6]. Khoiri, F., Utomo, B., Lesmana. 2014. Analisis Kelayakan Pengembangan Ekowisata Mangrove di Pantai Muara Indah Kecamatan Pantai Labu Kabupaten Deli Serdang. Jurnal Aquacoastmarine. 2 (1): 48-55. 